\title{
ASYMMETRIC ADJUSTMENT OF THE SECTORIAL LENDING- DEPOSIT RATE SPREAD IN FIJI
}

\author{
Shamal Shivneel Chand* and Baljeet Singh** \\ *School of Accounting, Finanace and Economics, The University of the South Pacific, Suva, Fiji. \\ ${ }^{* *}$ Corresponding author. School of Accounting, Finanace and Economics, The University of the South \\ Pacific, Suva, Fiji. Email: singh_bl@usp.ac.fj
}

\begin{abstract}
This study investigates the asymmetric adjustment of the sectorial lending-deposit rate spread in Fiji's banking industry using monthly data from January 2000 to February 2020. The study uses the threshold autoregressive and the momentum threshold autoregressive models to test for cointegration and to detect asymmetries. The analysis provides evidence of an asymmetric adjustment process in the sectorial lendingdeposit rate spread among Fijian commercial banks. This finding has important policy implications and provides better understanding of the asymmetric behaviour in Fiji's banking industry.
\end{abstract}

Keywords: Asymmetric adjustment; Lending-deposit spread; Threshold autoregressive models; Banking industry.

JEL Classifications: D8; G2; C2.

\author{
Article history: \\ Received : September 21, 2020 \\ Revised : December 1, 2020 \\ Accepted : December 8, 2020 \\ Available online : January 31, 2021 \\ https://doi.org/10.21098/bemp.v24i0.1468
}




\section{INTRODUCTION}

This paper empirically investigates the presence of asymmetric adjustment of the sectoral lending-deposit rate spread in the Fijian banking industry, a perspective shown from a small island developing state in the South Pacific. Earnings from interest rate spreads has been a major contributor to banks' profit and, hence, is a critical ingredient of financial stability. The significance of the financial sector in promoting economic growth is well established in the existing literature (Juhro et al., 2020; Phan et al., 2020; Ho \& Iyke, 2018; Adeniyi, et al., 2012; Ahmed \& Ansari, 1998). The banking sector, which dominates the financial sector in the Pacific Island countries, particularly in Fiji, plays a crucial role in mobilizing savings and providing financial services in the economy (Juhro et al., 2020). Changes in the interest rate spread not only reflect improvement in the banking sector efficiency, but also provide insights into the effectiveness of monetary policy and credit markets in the economy (Berument et al., 2014).

Numerous studies have noted asymmetric behaviour in bank deposit and lending rates (see e.g. Thompson, 2006; Nguyen and Islam, 2010; Enders \& Siklos, 2001). These studies found that banks are quick to increase the lending rate, following a rise in the market interest rate; however, they are slow in adjusting the lending rate downward when market interest rates are falling. A delayed downward adjustment of the lending rate can limit expansionary monetary policies' impact on the economy, such as Bernanke et al. (1996), Karras (1996), and Bernanke and Gertler (1995), observed asymmetric effects of sudden interest rate changes on real economic activity. A asymmetric behaviour by banks can be explained by four competing theoretical models in the literature (Scholnick, 1999; Thompson, 2006), namely information asymmetries, bank concentration hypothesis, consumer characteristic hypothesis, and the consumer reaction hypothesis.

The information asymmetries between banks and their customer base could be a potential driver of asymmetric adjustment in the interest rate spread (Thompson, 2006). Banks would be reluctant or slow to adjust their lending rates to declining market interest rates causing the interest rate spread to widen (Thompson, 2006). This occurs due to imperfect information when banks and customers enter into some business arrangement, making it costly for borrowers to switch to other lenders because of some established contractual agreement. The bank concentration hypothesis, on the other hand, states that banks in concentrated markets profit the most surplus from customers by adjusting their lending and deposit rates distinctly in response to changing market rates (Hannan \& Berger, 1991; Neumark \& Sharpe, 1992; Nguyen \& Islam, 2010). The banks in more concentrated markets are fast to adjust their lending rates upward, while reluctant to adjust them downward to changing market interest rates. Similarly, banks are fast to adjust their deposit rates downward than upward to equilibrium spread to extract the most surplus from lending.

Further, the consumer characteristic hypothesis argues that banks adjust their interest rates to maximise surpluses relative to the characteristics of heterogeneous customers (Rosen, 2002). The larger the number of inexperienced customers relative to sophisticated customers, while accounting for search costs, switch costs, and adverse selection problems, the slower the banks adjust their lending rates downward when deposit rate decreases (Calem \& Mester, 1995). On the contrary, 
the consumer reaction hypothesis by Stiglitz and Weiss (1981) states that banks are reluctant to adjust their lending rates upward due to possible negative reaction from the consumers. As such, consumers will benefit from asymmetric adjustment of interest rates in this case. Raising lending rates also have the potential to reduce banks' profit, since high interest rates could discourage safer investors from borrowing and could attract more risky investments. Weth (2002) noted that large banks in Germany were quick to adjust their lending rates in response to falling market rates due to a high risk of their customers switching to credit institutions offering attractive market rates. Several studies, using bank-level data, find sovereign bond yields, market concentration, bank size, and other individual bank characteristics are important determinants of interest rate spread (AliagaDíaz \& Olivero, 2011; Almeida \& Divino, 2015; Altunbaş et al., 2016; Holton \& d'Acri, 2018).

From this literature review, we observe that most of the existing studies examining the asymmetric response of banks to changing market interest rates used aggregate data or bank-level data, but not sectoral-level data (see Enders \& Siklos, 2001; Nguyen \& Islam, 2010; Thompson, 2006). However, interest rate spread generally differs across different sectors of the economy. For instance, the interest rate for personal loans is relatively higher than the interest rate on house loans, which has not been exclusively studied in existing literature. Further, studies mentioned are also heavily skewed to investigating asymmetric adjustment behaviour in highly developed or populated developing economies, but lack perspective on the issue from small island economies. In light of the above arguments, this study examines the asymmetric adjustment process in the lending-deposit rates spread for Fiji, a small island economy. More specifically, using unique banking data, this study examines the asymmetric adjustment behaviour of banks with respect to sector-related lending-deposit rate spread. We hypothesize that banks' asymmetric behaviour in lending-deposit rate spread differs across sectors of the Fijian economy. We use the threshold autoregressive (TAR) and and momentum TAR (MTAR) models proposed by Enders and Granger (1998) and Enders and Siklos (2001) to test our hypothesis for asymmetric adjustment behaviour among commercial banks. We investigate the asymmetric behaviour and possibly discriminatory adjustment of lending rates for nine sectors relative to changing time deposit rate. These sectors are agriculture, building and construction, manufacturing, non-bank financial institutions, professional and business services, private individuals, real estate, transport and storage, and wholesale and retail.

This study adds to the existing knowledge in the following manner. First, it provides empirical evidence of asymmetric behaviour of banks' lending-deposit spread in the context of a small island and remote country with a very limited and underdeveloped banking sector. Most prior studies examined the asymmetric behaviour of interest rates in developed nations with a well-developed and efficient banking sector (Enders \& Siklos, 2001; Nguyen \& Islam, 2010; Thompson, 2006) or developing countries with a larger banking sector (see Iyke, 2017a, b). Most Pacific Island countries, including Fiji, have only a few number banks with limited or no competition and the level of efficiency is relatively very low compare with developed countries. An analysis of asymmetric adjustment in the Fijian 
context provides insight into and evidence on interest adjustments by banks in a less competitive environment that otherwise is generally lacking in the literature.

Secondly, we examine the asymmetric adjustment behaviour of banks with respect to nine sector-related lending-deposit rate spread. Existing studies like Enders and Granger (1998), Nguyen and Islam (2010), and Thompson (2006) largely use aggregate data. As indicated in Figure 1, the lending-deposit rate spread (i.e. the difference between lending rate and deposit rate) vary across the time horizon for the weighted average (WA) lending rate. An evaluation of asymmetric adjustment for different categories of the lending facility will provide insight on the sectoral lending rates that are slower to adjust. An analysis at the sectoral level is generally lacking in the existing literature. An analysis of banks' response to changing interest rates will further enhance our understanding of how banks in small developing states are likely to adjust their sector-specific lending rates during the COVID-19 pandemic. $^{1}$

Figure 1.

The Lending-Deposit Rate Spread of Nine Sectors (January 2000-February 2020)

This graph shows the trends of the weighted average lending rate, time deposit rate, and the lending-deposit spread over the period from January 2000 to February 2020. The spread between the average lending rate and deposit rate has narrowed over the years.

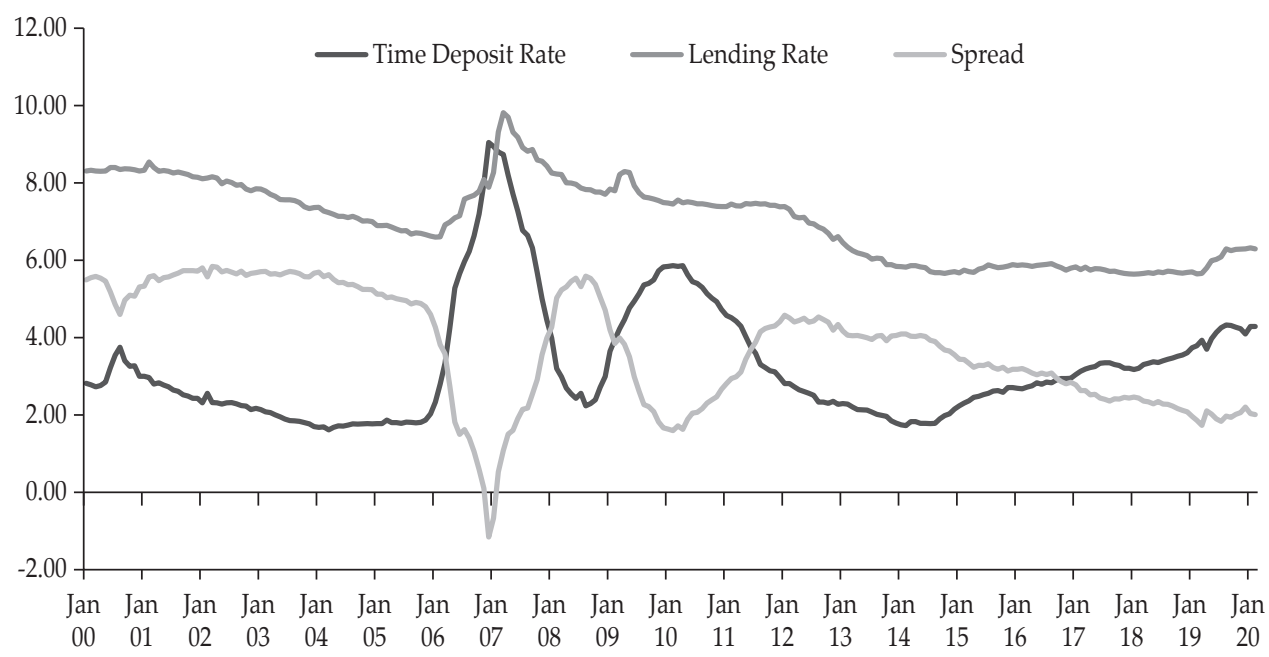

Overall, the findings indicate presence of asymmetric adjustment behaviour most sector-related lending-deposit spread. In particular, the lending-deposit spread are fast to revert to their long-run position when the spread is widening for agriculture, building and construction, manufacturing, non-bank financial

1 Recent studies have shown that the COVID-19 pandemic has created extreme uncertainty in and disruptions to economies and financial markets (see Devpura, 2020; Chen et al., 2020a; Gil-Alana \& Claudio-Quiroga, 2020; Han \& Qian, 2020; Iyke, 2020a, b; Iyke \& Ho, 2021; Narayan, 2020a, b, c; Prabheesh, 2020; Sharma, 2020). Hence, understanding the interest rate adjustment process during the pandemic would be very useful to policymakers in their quest to implement optimal policies to curb the negative consequences of the pandemic. 
institution, professional and business services, private individuals, real estate and wholesale, and retail sectors than when the spread is narrowing. The results indicate that banks in Fiji are reluctant to adjust their lending rates upward relative to rising deposit rates due to fear of a negative reaction from high profile customers and threats of customers switching to other banks offering attractive borrowing rates, which is consistent with the consumer reaction theory. For the transport and storage sector, the lending-deposit rate spread depicts symmetric adjustment process. These results are supported by robustness checks using the MTAR model in conjuction with the basic TAR model.

The rest of the paper is structured as follows. Section II outlines the nature of the Fijian banking industry. Section III outlines the methodology and data. Section IV discusses the empirical findings. Lastly, Section V concludes the paper and states the major policy implications.

\section{THE FIJIAN BANKING INDUSTRY}

The Fijian financial system is largely dominated by the banking industry (Sharma et al., 2014), consisting six commercial banks ${ }^{2}$, of which five are foreign-owned and four are credit institutions ${ }^{3}$ (Reserve Bank of Fiji, 2017). Apart from this, the insurance industry has nine insurers, four insurance brokers and 524 agents, while the Fiji National Provident Fund (FNPF) is the sole superannuation provider. Although Fiji has a single stock market, the South Pacific Stock Exchange, which is relatively small and mostly inactive with only a few listed companies on the exchange, and there exist no markets for money and corporate bonds (Sharma et al., 2014).

Commercial banks represent around 51 percent of the total financial sector assets, followed by FNPF with 34.8 percent, on average, between 2011 and 2017 (Asian Development Bank, 2019). The insurance and credit institutions only represent a minimal share of the financial sector. In 2003, the total asset of commercial banks was $\$ 2.6$ billion, representing around 59 percent of gross domestic product (GDP), which rose to $\$ 10$ billion in 2018, equivalent of 87 percent of GDP (see Figure 2). On the contrary, the total assets of credit institutions, on average, rose from $\$ 0.24$ billion (5.6 percent of GDP) in 2003 to $\$ 0.69$ billion (6.0 percent of GDP) in 2018. Despite the Reserve Bank of Fiji's total assets rising from $\$ 1.05$ billion in 2004 to $\$ 2.56$ billion in 2018 , it remained stagnant at 22 percent of GDP.

Commercial banks have been vital in supporting private sector credit growth together with declining lending rates (Asian Development Bank, 2019). Private sector credit grew from $\$ 2.85$ billion in 2011 to $\$ 4.59$ billion in 2017, an average growth of 8.3 percent per year representing 82 percent of GDP. The number of bank branches increased from 63 in 2011 to 70 in 2017, while the number of automated teller machines (ATMs) rose by 45 percent to 325 machines in 2017.

2 These banks are Australia and New Zealand Banking Corporation Limited (ANZ), Bank of Baroda, Bank of South Pacific Limited (BSP), BRED Bank Limited, Westpac Banking Corporation Limited, and the locally-owned bank, Home Finance Company Limited (HFC).

3 These credit institutions are BSP Finance (Fiji) Limited, Credit Corporation (Fiji) Limited, Kontiki Finance Limited, and Merchant Finance Limited. 
Figure 2.

Banking Sector Assets to GDP (2003-2018)

The graph shows the commercial bank, the Reserve Bank of Fiji, and credit institutions' total assets to nominal GDP. The data is sourced from the Reserve Bank of Fiji and the Fiji Bureau of Statistics.

Assets to GDP (\%)

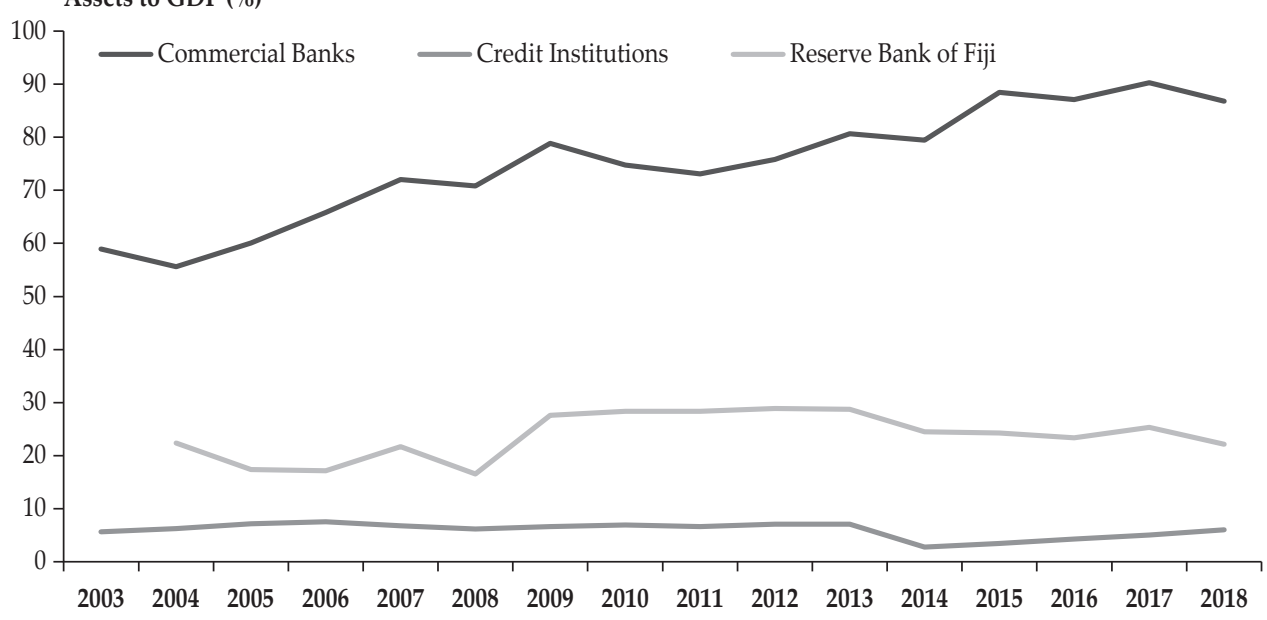

The cumulative time, savings, and demand deposit, in aggregate, has grown by an average of 9.3 percent per year, while the lending component grew by 7.6 percent per year (Table 1) between 2014 and 2018. The same period experienced drastic growth in both savings deposit rate from 0.57 percent in 2014 to 1.32 percent in 2018, and time deposit rate from 2.15 percent in 2014 to 3.61 percent in 2018. On the other hand, the weighted average lending rate has marginally decreased from 5.71 percent in 2014 to 5.69 percent in 2018, while growing by almost 18 basis points in 2015. According to the Reserve Bank of Fiji (2015), the lending and deposit rates had major increment in 2015 as a result of rapid economic growth, and increased activities in the real estate, building, and construction sectors.

Improvement in banking services over the years has been vital in providing greater access to financial services to Fijians. Remittances, one of the largest transfer inflows for many Fijians, has been found to be the major factor in private sector credit growth (Chen et al., 2020b). However, according to the Reserve Bank of Fiji (2015), banking services are largely clustered in the urban areas and around 27 percent of adults have limited or no access to financial services, most of whom are women, youth, and rural inhabitants. The banking industry has undergone several reforms over the years to streamline broader financial access and ensure adequate liquidity levels. These include the transformation of savings banks to full commercial banks in 1976, the introduction of ATMs in 1993, the introduction of Electronic Funds Transfer at Point of Sale (EFTPOS) machines in 1995, and the introduction of mobile money in 2010 (Reserve Bank of Fiji, 2017). 
Table 1.

Deposit and Lending Trend (2014-2018)

This table presents the general trends of commercial banks' deposit and lending components. The data is sourced from the Reserve Bank of Fiji.

\begin{tabular}{|c|c|c|c|c|c|c|}
\hline $\begin{array}{l}\text { Commercial Bank } \\
\text { Components }\end{array}$ & 2014 & 2015 & 2016 & 2017 & 2018 & $\begin{array}{l}\text { Average } \\
\text { Growth }\end{array}$ \\
\hline & \multicolumn{5}{|c|}{$\$$ millions } & \\
\hline Deposit & $4,835.0$ & $5,479.8$ & $5,986.4$ & $6,488.5$ & $6,893.0$ & $9.3 \%$ \\
\hline \multirow[t]{2}{*}{ Loans and Advances } & $5,757.8$ & $6,575.7$ & $6,877.0$ & $7,565.1$ & $7,696.1$ & $7.6 \%$ \\
\hline & \multicolumn{5}{|c|}{ Rates in percent } & \\
\hline Deposits - Savings & 0.57 & 1.01 & 0.97 & 1.34 & 1.32 & $0.19 \%$ \\
\hline Deposits - Time & 2.15 & 2.71 & 2.95 & 3.21 & 3.61 & $0.36 \%$ \\
\hline Loans and Advances & 5.71 & 5.89 & 5.80 & 5.65 & 5.69 & $-0.004 \%$ \\
\hline
\end{tabular}

\section{METHODOLOGY AND DATA}

\section{A. Methods}

We employ the threshold cointegration methodology proposed by Enders and Siklos (2001) to investigate the asymmetric adjustment behaviour in the lendingdeposit rate spread of the Fijian banking industry. In comparison, the standard cointegration frameworks, which include the Engle and Granger two-stage residual-based cointegration, the Johansen cointegration, and the autoregressive distributed lag cointegration approaches, assume symmetric adjustment in the long-run (see Iyke, 2017a, b; Prabheesh \& Laila, 2020). However, if in reality, the long-run adjustment is asymmetric and, hence, the model is supposedly mis-specified when applying these cointegration frameworks. The threshold cointegration methodology consists of two models, namely the TAR and MTAR models. Our modelling approach is consistent with Enders and Siklos (2001), Thompson (2006), Nguyen and Islam (2010), and Iyke (2017a, b). We hypothesize that the adjustment process of the lending-deposit rate spread in Fiji is asymmetric. The lending-deposit rate spread is computed as the arithmetic difference between the sectorial lending rate and the time deposit rate. The time deposit rate is used as the proxy for the deposit rate. Since time deposits have a fixed maturity with higher rates as compared to savings deposits, their rates form as the base rates for banks in setting up their lending rates. In addition, the time deposit rate tends to follow the lending rates quite closely upon further investigation. Further, the sectorial lending-deposit rate spread is regressed on a constant and the intercept dummies, structural breaks, and the estimated residuals are saved as $S^{r}$ for model estimation and hypotheses testing. The structural breaks used in the estimation process are listed in Table 4 . The TAR model is outlined as follows:

$$
\Delta S_{t}^{r}=I_{t} \rho_{1} S_{t-1}^{r}+\left(1-I_{t}\right) \rho_{2} S_{t-1}^{r}+\sum_{i=1}^{n} \delta_{i} \Delta S^{r}{ }_{t-i}+\varepsilon_{t}
$$

where $\rho_{1}$ and $\rho_{2}$ are the adjustment parameters for above and below thresholds, which are expected to be significant and should lie between zero and negative one for the assumption of asymmetric adjustment to hold. $\varepsilon_{t}$ is the disturbance term and $I_{t}$ is the Heaviside indicator function defined as follows: 


$$
I_{t}=\left\{\begin{array}{l}
1 \text { if } S^{r}{ }_{t-1} \geq \tau \\
0 \text { if } S^{r}{ }_{t-1}<\tau
\end{array}\right.
$$

where $\tau$ is the threshold value that can be either zero or non-zero (unknown). Chan (1993) provides an approach to estimate a super-consistent threshold value by minimising the sum of squared errors used in this study. The threshold value is estimated by first obtaining 70 percent of the residuals through arranging the residuals in ascending order and removing 15 percent of residual values from each side of tail. The threshold value is one that minimized the residual sum of squares after iterative model estimation for all threshold values. Overall, if $S_{t-1}$ is above the threshold, then the speed of adjustment in Equation (2) is $\rho_{1} S_{t-1}$, whereas if $S_{t-1}$ is below the threshold, the adjustment is $\rho_{2} S_{t-1}$. The adjustment parameters provide valuable information on the adjustment behaviour. For instance, if $\rho_{2}$ is greater than $\rho_{1}$, than negative disequilibrium is more persistent than positive disequilibrium toward the threshold.

On the other hand, the adjustment could also depend on the first difference of $S_{t-1}$ and not only the levels. This process is given by as the MTAR model and the Heaviside indicator function defined as in Equation (3):

$$
I_{t}=\left\{\begin{array}{c}
1 \text { if } \Delta S^{r}{ }_{t-1} \geq \tau \\
0 \text { if } \Delta S^{r}{ }_{t-1}<\tau
\end{array}\right.
$$

As opposed to the TAR model in Equation (2), which only captures asymmetrically deep movements, the MTAR model in Equation (3) is more suited in situations when the momentum is prevalent in one particular direction or has relatively asymmetrically "sharp" movements. For instance, if $\left|\rho_{1}\right|$ is greater than $\left|\rho_{2}\right|$ than positive shocks tend to coverge to the threshold quickly, whereas the negative shocks persist. According to Enders and Siklos (2001), the power of the MTAR test is significantly larger than the Engle-Granger test as well as the TAR test for cointegration.

The diagnostic tests for both the TAR and MTAR models are as follows. The null hypothesis of no cointegration $\left(\rho_{1}=\rho_{2}=0\right)$ is tested against the alternative of cointegration using joint $F$-statistics. When the null hypothesis of no cointegration is rejected, the test for asymmetric adjustment is then applied. The null hypothesis, which is symmetric adjustment $\left(\rho_{1}=\rho_{2}\right)$ is tested against the alternative using equal $F$-statistic. We obtain the critical values for cointegration and asymmetric adjustment tests from Enders and Siklos (2001). When both tests are rejected, the adjustment in the lending-deposit rate spread is deemed asymmetric.

\section{B. Data}

This paper used monthly data from January 2000 to February 2020, with 242 observations for the time deposit rate $(D R)$ and the lending rates $(L R)$ for agriculture $(A G R)$, manufacturing $(M A N)$, building and construction $(B C)$, real estate $(R E)$, wholesale and retail (WR), transport \& storage (TS), non-bank financial institutions $(N B F I)$, professional and business services $(P B S)$, and private individuals $(P I)$. The 
non-bank financial institutions' lending rate comprises two statutory lenders, two money changers, nine foreign exchange dealers, 89 co-operatives and 21 credit unions (Reserve Bank of Fiji, 2017). This data can be obtained from the Reserve Bank of Fiji. Commercial banks charge different lending rates on loans and advances to nine sectors of the Fijian economy. The differing rates show commercial banks' risk aversion behaviour toward different sectors with respect to their overall credit rating. The sectorial lending and deposit rates utilized in this study are from the commercial banks of Fiji as they are the only institutions engaged in lending and deposit financial activities. Monthly data is only available from January 2000 to February 2020.

The descriptive statistics is provided in Table 2. Over the sample period, the average time deposit rate was 3.28 percent, reaching its highest of 9.05 percent in late 2006 due to limited liquidity in banks (Prasad, 2017). The average lending rate for the agriculture sector is relatively high (8.55 percent) compared to other sectors due to higher associated credit risks and the sector being vulnerable to frequent natural disasters as well as business and financial risks (Li et al., 2013). The lowest average lending rate was recorded by the manufacturing and wholesale and retail, which reflects the lower associated credit risk in these sectors relative to others.

Table 2.

Summary Statistics of Deposit and Lending Rates (January 2000-February 2020)

This table presents the descriptive analysis of the key variables. The statistics are the mean, maximum, minimum, standard deviation (Std. Dev.), skewness, and Jarque-Bera. The abbreviations are as follows: Lending Rate (LR), Deposit Rate (DR), Agriculture (AGR), Building and Construcition (BC), Manufacturing (MAN), Non-Bank Financial Institutions (NBFI), Professional and Business Services (PBS), Private Individuals (PI), Real Estate (RE), Transport and Storage (TS) and Wholesale and Retail (WR) and Weighted Average (WA).

\begin{tabular}{lcccccc}
\hline Indicators & Mean & Maximum & Minimum & Std. Dev. & Skewness & Jarque-Bera \\
\hline DR & 3.28 & 9.05 & 1.61 & 1.55 & 1.56 & 153.97 \\
LR AGR & 8.55 & 11.38 & 6.14 & 1.56 & -0.13 & 22.12 \\
LR BC & 7.03 & 10.55 & 4.82 & 1.43 & -0.10 & 9.97 \\
LR MAN & 6.33 & 8.88 & 4.71 & 1.06 & 0.01 & 13.15 \\
LR NBFI & 7.90 & 14.26 & 5.39 & 1.36 & 0.82 & 72.97 \\
LR PBS & 7.61 & 10.73 & 6.06 & 0.95 & 0.21 & 8.40 \\
LR PI & 8.19 & 10.26 & 7.02 & 0.75 & 0.61 & 15.02 \\
LR RE & 6.57 & 10.72 & 4.69 & 1.39 & 0.30 & 9.76 \\
LR TS & 7.46 & 9.52 & 5.69 & 1.08 & 0.36 & 20.04 \\
LR WR & 6.34 & 9.98 & 4.49 & 1.20 & 0.21 & 4.73 \\
LR WA & 7.04 & 9.82 & 5.64 & 1.03 & 0.13 & 11.19 \\
\hline
\end{tabular}

\section{MAIN FINDINGS}

A. Unit Root Test

The unit root test results are presented in Table 3. As per the ADF test, all the variables are stationary at first difference except for the NBFI lending rate. Similar results are obtained from the Phillips-Perron unit root test where the null hypothesis of unit root cannot be rejected for the deposit rate at one percent significance level. Both tests fail to reject the null hypothesis of unit root for the NBFI lending rate in level form at one percent significance. The nonlinear unit root 
test by Narayan and Popp (2010) that allows two structurual breaks is also applied as shown in Table 4. Overall, the nonlinear unit root test results are consistent with the linear unit root test results, i.e. the ADF and Phillips-Perron test results. In the next step, we use the threshold cointegration test as proposed by Enders and Siklos (2001) to test for cointegration and asymmetric adjustment.

Table 3.

\section{Augmented Dickey-Fuller and Phillips-Perron Unit Root Test Results}

This table presents the unit root test results using the Augmented Dickey-Fuller (ADF) and Phillip-Perron (PP) tests. The critical value is 3.43 at 5 percent significance level. The maximum lag selection is based on Akaike Information Criterion and both intercept and trend are included in the test equation. The abbreviations are as follows: Lending Rate (LR), Deposit Rate (DR), Agriculture (AGR), Building and Construcition (BC), Manufacturing (MAN), Non-Bank Financial Institutions (NBFI), Professional and Business Services (PBS), Private Individuals (PI), Real Estate (RE), Transport and Storage (TS) and Wholesale and Retail (WR).

\begin{tabular}{lcccccccc}
\hline \multirow{2}{*}{ Indicator } & \multicolumn{2}{c}{ ADF (Level) } & \multicolumn{2}{c}{$\begin{array}{c}\text { ADF (1st } \\
\text { Difference) }\end{array}$} & \multicolumn{2}{c}{ PP (Level) } & \multicolumn{2}{c}{ PP (1st Difference) } \\
\cline { 2 - 9 } & Test & $p$-value & Test & $p$-value & Test & $p$-value & Test & $p$-value \\
\hline DR & -2.57 & 0.29 & -15.46 & 0.00 & -3.82 & 0.02 & -20.79 & 0.00 \\
LR AGR & -2.16 & 0.51 & -17.74 & 0.00 & -2.01 & 0.59 & -17.73 & 0.00 \\
LR BC & -1.88 & 0.66 & -14.39 & 0.00 & -2.16 & 0.51 & -14.44 & 0.00 \\
LR MAN & -2.62 & 0.27 & -15.12 & 0.00 & -2.45 & 0.35 & -15.38 & 0.00 \\
LR NBFI & -4.91 & 0.00 & -15.32 & 0.00 & -7.54 & 0.00 & -29.10 & 0.00 \\
LR PBS & -3.48 & 0.04 & -12.95 & 0.00 & -3.00 & 0.13 & -19.33 & 0.00 \\
LR PI & -2.42 & 0.37 & -5.52 & 0.00 & -2.07 & 0.56 & -11.12 & 0.00 \\
LR RE & -2.66 & 0.26 & -19.28 & 0.00 & -2.72 & 0.23 & -19.02 & 0.00 \\
LR TS & -2.45 & 0.35 & -19.05 & 0.00 & -2.90 & 0.16 & -19.77 & 0.00 \\
LR WR & -3.09 & 0.11 & -19.94 & 0.00 & -2.76 & 0.21 & -20.78 & 0.00 \\
LR WA & -2.06 & 0.56 & -10.62 & 0.00 & -1.93 & 0.64 & -10.53 & 0.00 \\
\hline
\end{tabular}

Table 4.

Narayan and Popp Nonlinear Unit Root Test

This table presents the Narayan and Popp (2010) nonlinear unit root test results that allows two structural breaks. M1 (model 1) allows for two breaks in level and M2 (model 2) allows for two breaks in the level as well as the slope. TB1 and TB2 are the potential structural break points when testing for unit root. ${ }^{* *}$ and ${ }^{*}$ represent significance at 5 and 10 percent, respectively, while $\mathrm{k}$ is the maximum lag order. The critical values for the tests are obtained from Narayan and Popp (2010). Spread is the arithmetic difference between the lending rate and the deposit rate. For instance, the AGR indicator in the table below is the difference between the agriculture lending rate and the time deposit rate. Abbreviations for other spreads between lending and deposit rates are BC - Building and Construction, MAN - Manufacturing, NBFI - Non-Bank Financial Institutions, PBS - Professional and Business Services, PI - Private Individuals, RE - Real Estate, TS - Transport and Storage, WR - Wholesale and Retail and WA - Weighted Average.

\begin{tabular}{|c|c|c|c|c|c|c|c|c|}
\hline \multirow[b]{2}{*}{ Spread } & \multicolumn{4}{|c|}{ M1 } & \multicolumn{4}{|c|}{ M2 } \\
\hline & $\begin{array}{c}\text { Test } \\
\text { Statistic }\end{array}$ & TB1 & TB2 & k & $\begin{array}{c}\text { Test } \\
\text { Statistic }\end{array}$ & TB1 & TB2 & k \\
\hline$A G R$ & -2.532 & 2007M01 & 2012M04 & 3 & -2.522 & 2007M01 & 2012M04 & 3 \\
\hline$B C$ & -1.485 & 2006M11 & 2007M01 & 3 & -1.581 & 2006M11 & 2007M01 & 3 \\
\hline MAN & -1.395 & 2006M11 & 2007M04 & 4 & -3.215 & 2006M11 & 2012M03 & 1 \\
\hline NBFI & $-4.637^{* *}$ & 2012M04 & 2012M06 & 1 & $-4.648^{*}$ & 2012M04 & 2012M06 & 1 \\
\hline PBS & $-4.085^{*}$ & 2006M03 & 2007M01 & 3 & -4.383 & 2006M03 & 2007M01 & 3 \\
\hline PI & -0.628 & 2006M12 & 2007M02 & 2 & -1.062 & $2006 \mathrm{M} 12$ & 2007M03 & 2 \\
\hline
\end{tabular}


Table 4.

Narayan and Popp Nonlinear Unit Root Test (Continued)

\begin{tabular}{lcccccccc}
\hline \multirow{2}{*}{ Spread } & \multicolumn{9}{c}{ M1 } & \multicolumn{7}{c}{ M2 } \\
\cline { 2 - 9 } & $\begin{array}{c}\text { Test } \\
\text { Statistic }\end{array}$ & TB1 & TB2 & $\mathbf{k}$ & $\begin{array}{c}\text { Test } \\
\text { Statistic }\end{array}$ & TB1 & TB2 & $\mathbf{k}$ \\
\hline RE & -3.108 & $2006 \mathrm{M} 03$ & $2007 \mathrm{M} 01$ & 2 & -3.205 & $2006 \mathrm{M} 03$ & $2007 \mathrm{M} 01$ & 2 \\
TS & $-4.262^{* *}$ & $2006 \mathrm{M} 04$ & $2012 \mathrm{M} 03$ & 5 & -4.244 & $2006 \mathrm{M} 04$ & $2012 \mathrm{M} 03$ & 5 \\
WR & -3.314 & $2006 \mathrm{M} 11$ & $2012 \mathrm{M} 04$ & 5 & -1.104 & $2007 \mathrm{M} 01$ & $2012 \mathrm{M} 04$ & 2 \\
WA & -1.979 & $2006 \mathrm{M} 11$ & 2007M04 & 4 & -4.345 & $2006 \mathrm{M} 03$ & $2006 \mathrm{M} 012$ & 3 \\
\hline
\end{tabular}

\section{B. Multiple Breakpoint Test}

We apply the Bai-Perron approach to test for multiple breakpoints. We suspect that due to structural changes in the Fijian economic system and to various financial sector reforms over the years, the banking industry might have experienced significant transformation. We test this and report the results in Table 5. The results show evidence of significant structural changes in the banking industry. The breakpoints/structural are accommodated in estimating the residuals of lendingdeposit rate spread when testing for threshold cointegration and asymmetric adjustment processes. Accounting for these structural breaks in the test improved our overall results and provided robust estimates.

Table 5.

\section{Multiple Structural Breakpoint Test}

This table outlines the Bai-Perron breakpoint test results. The structural breakpoints were selected based on the Schwarz Information Criterion with a maximum of 5 breaks allowed in the test. The estimated break dates are presented in yearly and monthly (numbered) format which are accommodated in the equation when deriving lending-deposit rate spread's residuals. Spread is the arithmetic difference between the lending rate and the deposit rate. For instance, the $A G R$ indicator in the table below is the difference between the agriculture lending rate and the time deposit rate. Abbreviations for other spreads between lending and deposit rates are BC - Building and Construction, MAN - Manufacturing, NBFI - Non-Bank Financial Institutions, PBS - Professional and Business Services, PI - Private Individuals, RE - Real Estate, TS - Transport and Storage, WR - Wholesale and Retail and WA - Weighted Average.

\begin{tabular}{|c|c|c|c|c|c|}
\hline \multirow{2}{*}{$\begin{array}{l}\text { Spread } \\
A G R\end{array}$} & \multirow{2}{*}{$\begin{array}{c}\begin{array}{c}\text { Schwarz } \\
\text { Criterion }\end{array} \\
0.159\end{array}$} & \multicolumn{2}{|c|}{ Multiple breakpoints } & & \\
\hline & & $2005 \mathrm{M} 07$ & $2008 \mathrm{M} 07$ & $2015 \mathrm{M} 01$ & \\
\hline$B C$ & -0.283 & 2006M01 & 2011M06 & 2015M02 & \\
\hline MAN & -0.03 & 2006M02 & 2011M06 & 2015M03 & \\
\hline NBFI & 0.692 & 2003M01 & 2006M01 & 2010M10 & \\
\hline PBS & -0.101 & 2006M04 & 2011M04 & 2014M12 & \\
\hline PI & 0.083 & 2006M02 & 2011M07 & 2017M03 & \\
\hline$R E$ & -0.313 & 2003M04 & 2006M04 & 2011M05 & 2014M12 \\
\hline TS & 0.198 & 2006M02 & 2011M05 & 2015M08 & \\
\hline$W R$ & -0.132 & 2006M02 & 2011M03 & 2014M03 & 2017M03 \\
\hline WA & -0.135 & $2006 \mathrm{M} 02$ & 2011M03 & 2015M08 & \\
\hline
\end{tabular}




\section{Threshold Cointegration and Asymmetric Adjustment Test}

Enders and Siklos (2001) recommended testing threshold cointegrating relationship using either the joint F-test $\left(\rho_{1}=\rho_{2}=0\right)$ or the $t$-Max test. In this study we use the former given the low power of the $t$-Max test to investigate the asymmetric adjustment process. The lag changes in residuals was chosen using the Schwarz Information Criterion with a maximum of 10 lags allowed in the test. The joint $F$-statistics are reported for the cointegration and asymmetric adjustment tests and the critical values are from Enders and Siklos (2001).

Table 6 reports the test results for the threshold cointegration and asymmetric adjustment process based on the TAR and MTAR models. The results are presented by sector, whereby both the TAR and MTAR models are estimated for each sector's spread. The threshold values for both the TAR and MTAR models were obtained using Chan (1993) procedure based on the criteria of the minimized sum of squared residuals. Also, the diagnostic analysis for the TAR and MTAR models indicate the absence of serial correlation from the Ljung-Box $Q$-statistics at 8 lags.

In order to test for threshold cointegration, the null hypothesis of $\rho_{1}=\rho_{2}=0$ is compared against the critical values given by Enders and Siklos (2001) at one, five and 10 percent levels of statistical significance. Therefore, it is possible to reject the null hypothesis of no cointegration $\left(\rho_{1}=\rho_{2}=0\right)$ at one percent significant level for both models of all sectors in the study. Further, we test the null hypothesis of $\rho_{1}=\rho_{2}$ (symmetric adjustment) for all sectors after establishing cointegration. The null hypothesis of symmetric adjustment is only rejected for agriculture and non-bank financial institutions and the overall weighted average (WA) under the TAR model at 10 percent significance level, while other sectors' lending-deposit rate spread exhibit symmetric adjustment process. Hence, the TAR model indicates that the agriculture and weighted average lending-deposit rate spread tend to adjust to its long run equilibrium faster when the spread is below the threshold than when it is above. However, the non-bank financial institutions' lending-deposit rate tends to revert to its long-run equilibrium faster when the spread is above the threshold than when it is below.

The MTAR model does not only reject the null hypothesis of symmetric adjustment, but also shows a significant presence of asymmetric adjustment $\left(\rho_{1} \neq \rho_{2}\right)$ process for agriculture, building and construction, manufacturing, nonbank financial institutions, professional and business services, private individuals, real estate and the wholesale and retail sectors as well as the overall weighted average. On the other hand, we failed to reject the null hypothesis of symmetric adjustment for the transport and storage lending-deposit spread.

Under the MTAR model, the asymmetric adjustment process is homogeneous across all sectorial lending-deposit spread. Given that $\rho_{1}>\rho_{2}$ across all sectorial spread except for transport and storage, this indicates that the spread tends to tremendously persist toward the thresholds when the lending-deposit rate spread is narrowing (rising deposit rate) than when the spread is widening (falling deposit rate). In similar terms, the lending-deposit rate spread is faster to adjust to the threshold when the spread is widening (falling deposit rate) than when the spread is narrowing (rising deposit rate). The MTAR model, therefore, supports our hypothesis that the commercial banks in Fiji adjust the lending rates differently to rising versus falling deposit rates. This empirical finding is consistent 
with Nguyen and Islam (2010) as well as the consumer reaction theory by Stiglitz and Weiss (1981). This finding contradicts Thompson's (2006) finding, in terms of direction of adjustment.

Table 6.

\section{Threshold Cointegration and Asymmetric Adjustment Test}

This table reports the result from TAR and MTAR models. ${ }^{* * *}{ }^{* *}$ and ${ }^{*}$ indicate significance at 1,5 and 10 percent levels. The estimated parameters, test statistics, and critical values are rounded off to three decimal places. The critical values for the joint $F$-test $\left(\rho_{1}=\rho_{2}=0\right)$ for threshold cointegration and $F$-equal test $\left(\rho_{1}=\rho_{2}\right)$ for asymmetric adjustment at 5 percent significance levels was obtained from Enders and Siklos (2001). The threshold value is $\tau$ and the optimum lag length is selected on using the general-to-specific approach. Spread is the arithmetic difference between the lending rate and the deposit rate. For instance, $A G R$ indicator in the table is the difference between the agriculture lending rate and the time deposit rate. The Ljung-Box $Q$-statistic provides the test for serial correlation at 8 lags with the null hypothesis of no serial correlation. Abbreviations for other spreads between lending and deposit rates are BC Building and Construction, MAN - Manufacturing, NBFI - Non-Bank Financial Institutions, PBS - Professional and Business Services, PI - Private Individuals, RE - Real Estate, TS - Transport and Storage, WR - Wholesale and Retail and WA - Weighted Average.

\begin{tabular}{|c|c|c|c|c|c|c|c|c|}
\hline Spread & Model & $\rho_{1}$ & $\rho_{2}$ & $\tau$ & $\rho_{1}=\rho_{2}=0$ & $\rho_{1}=\rho_{2}$ & AIC & $Q(8)$ \\
\hline \multirow{2}{*}{$A G R$} & TAR & $-0.122^{* * *}$ & $-0.202^{* * *}$ & -0.707 & $15.655^{* * *}$ & $2.806^{*}$ & 0.846 & $2.668[0.953]$ \\
\hline & MTAR & $-0.202^{* * *}$ & $-0.086^{*}$ & -0.214 & $17.775^{* * *}$ & $4.817^{* *}$ & 0.844 & $1.155[0.997]$ \\
\hline \multirow{2}{*}{$B C$} & TAR & $-0.132^{* * *}$ & $-0.209^{* * *}$ & 0.318 & $13.401^{* * *}$ & 2.112 & 0.629 & $0.558[1.000]$ \\
\hline & MTAR & $-0.260^{* * *}$ & $-0.095^{* *}$ & 0.021 & $17.588^{* * *}$ & $9.658^{* * *}$ & 0.596 & $1.394[0.994]$ \\
\hline \multirow{2}{*}{ MAN } & TAR & $-0.081^{* *}$ & $-0.137^{* * *}$ & -0.653 & $8.083^{* * *}$ & 1.393 & 0.678 & $2.315[0.970]$ \\
\hline & MTAR & $-0.228^{* * *}$ & $-0.065^{* *}$ & 0.143 & $12.320^{* * *}$ & $9.343^{* * *}$ & 0.643 & $3.438[0.904]$ \\
\hline \multirow{2}{*}{ NBFI } & TAR & $-0.415^{* * *}$ & -0.102 & 1.021 & $14.877^{* * *}$ & $-3.085^{* * *}$ & 2.841 & $2.039[0.980]$ \\
\hline & MTAR & $-0.548^{* * *}$ & $-0.125^{*}$ & 0.252 & $24.744^{* * *}$ & $17.851^{* * *}$ & 2.799 & $2.808[0.946]$ \\
\hline \multirow{2}{*}{ PBS } & TAR & $-0.084^{* *}$ & $-0.129^{* * *}$ & -0.429 & $9.463^{* * *}$ & 0.991 & 0.52 & $1.438[0.994]$ \\
\hline & MTAR & $-0.208^{* * *}$ & -0.018 & -0.062 & $18.562^{* * *}$ & $17.861^{* * *}$ & 0.449 & $2.309[0.970]$ \\
\hline \multirow{2}{*}{ PI } & TAR & $-0.099^{* * *}$ & $-0.153^{* * *}$ & -0.605 & $16.239^{* * *}$ & 2.332 & 0.202 & $0.727[0.999]$ \\
\hline & MTAR & $-0.159^{* * *}$ & $-0.071^{* *}$ & -0.152 & $17.959^{* * *}$ & $5.368^{* *}$ & 0.189 & $0.5983[1.000]$ \\
\hline \multirow{2}{*}{$R E$} & TAR & $-0.076^{* *}$ & $-0.123^{* * *}$ & -0.512 & $6.759^{* * *}$ & 0.748 & 0.546 & $6.169[0.628]$ \\
\hline & MTAR & $-0.194^{* * *}$ & $-0.075^{* *}$ & 0.148 & $9.812^{* * *}$ & $4.185^{* *}$ & 0.536 & $10.853[0.210]$ \\
\hline \multirow{2}{*}{ TS } & TAR & $-0.134^{* * *}$ & $-0.126^{* * *}$ & 0.461 & $11.278^{* * *}$ & 0.027 & 1.016 & $4.368[0.823]$ \\
\hline & MTAR & $-0.112^{* * *}$ & $-0.141^{* * *}$ & -0.01 & $10.600^{* * *}$ & 0.32 & 1.015 & $5.785[0.671]$ \\
\hline \multirow{2}{*}{$W R$} & TAR & $-0.123^{* * *}$ & $-0.153^{* * *}$ & 0.304 & $10.225^{* * *}$ & 0.312 & 0.697 & $1.099[0.998]$ \\
\hline & MTAR & $-0.229^{* * *}$ & $-0.086^{* *}$ & 0.092 & $13.843^{* * *}$ & $6.954^{* * *}$ & 0.668 & $1.361[0.995]$ \\
\hline \multirow{2}{*}{$W A$} & TAR & $-0.062^{* *}$ & $-0.129^{* * *}$ & -0.551 & $8.824^{* * *}$ & $2.866^{*}$ & 0.201 & $3.499[0.899]$ \\
\hline & MTAR & $-0.151^{* * *}$ & $-0.076^{* * *}$ & 0.002 & $13.531^{* * *}$ & $3.364^{*}$ & 0.198 & $3.749[0.879]$ \\
\hline
\end{tabular}

Overall, the MTAR model generally supports our hypothesis because it detects asymmetric adjustment process in the sectorial lending-deposit rate spread as compared to the TAR model. The results of the MTAR model is more reliable given that it produces the lowest Akaike Information Criterion than the TAR model, as evidenced in Table 6. Similarly, Enders and Granger (1998) and Enders and Siklos (2001) also refer to greater predictive power of the MTAR model over the TAR model. 


\section{CONCLUSION AND POLICY IMPLICATIONS}

The Fijian banking sector has gone through a number of reforms over the years due to changes in both the economic and political environment. The finding of asymmetric adjustment behaviour in sector-specific lending-deposit rate spread has important policy implications. This study immensely contributes to the adjustment behaviour in the lending-deposit spread in the Fijian banking industry and is the first to provide evidence of discriminatory asymmetric adjustment in lending-deposit spread at the sectorial level of the economy.

The MTAR model shows that lending-deposit rate spread are fast to adjust to the long-run position when the spread is widening (falling deposit rate) than when the spread is narrowing (rising deposit rate) for the agriculture, building and construction, manufacturing, non-bank financial institutions, professional and business services, private individuals, real estate and wholesale and retail sectors as well as the overall weighted average lending-deposit rate spread. On the other hand, the transport and storage sectors'lending-deposit rate spread has symmetric adjustment behaviour. The asymmetric adjustment process is homogeneous across eight sectors and is explained by the consumer reaction theory of Stiglitz and Weiss (1981). The results indicate that Fijian banks are reluctant to adjust their lending rates upward relative to rising deposit rates because of fear of a negative reaction from high profile customers and threats of customers switching to other banks offering attractive borrowing rates. In fact, the banks are fast to adjust their lending rates downward for these sectors when deposit rates decrease for positive feedback and to attract other highly lucrative customers.

Our findings do not only provide empirical evidence of the asymmetric adjustment process of the interest spread in Fiji, but also have major policy implications. The lending-deposit rate spread is found to adjust faster to longrun equilibrium when the spread is widening than when the spread is narrowing. This implies that quantitative easing policies of the central bank is likely to have an immediate positive impact on all sectors of the economy. The central bank can effectively use quantitative easing monetary policies to boost economic activities in most sectors when the economy is showing signs of slow down or stagnation. A fall in the deposit rate will have an immediate downward pressure on the lending rates of the commercial banks across most sectors of the economy. This observation is particularly relevant to addressing the adverse impact of COVID-19 on the economy.

\section{REFERENCES}

Adeniyi, O., Omisakin, O., Egwaikhide, F. O., \& Oyinlola, A. (2012). Foreign Direct Investment, Economic Growth and Financial Sector Development in Small Open Developing Economies. Economic Analysis and Policy, 42, 105-127. https:// doi.org/10.1016/S0313-5926(12)50008-1

Ahmed, S. M., \& Ansari, M. I. (1998). Financial Sector Development and Economic Growth: The South-Asian Experience. Journal of Asian Economics, 9, 503-517.

Aliaga-Díaz, R., \& Olivero, M. P. (2011). The Cyclicality Of Price-Cost Margins in Banking: An Empirical Analysis of Its Determinants. Economic Inquiry, 49, $26-46$. 
Almeida, F. D., \& Divino, J. A. (2015). Determinants of the Banking Spread in The Brazilian Economy: The Role of Micro And Macroeconomic Factors. International Review of Economics \& Finance, 40, 29-39.

Altunbaş, Y., Di Tommaso, C., \& Thornton, J. (2016). Is There A Financial Accelerator in European Banking? Finance Research Letters, 17, 218-221.

Asian Development Bank. (2019). Pacific Finance Sector Brief: Fiji [Press release]. Retrieved from https://www.adb.org/sites/default/files/publication/529841/ pacific-finance-sector-fiji.pdf

Bernanke, B., \& Gertler, M. (1995). Inside the Black Box: The Credit Channel of Monetary Policy Transmission. Journal of Economic perspectives, 9, 27-48.

Bernanke, B., Gertler, M., \& Gilchrist, S. (1996). The Financial Accelerator and The Flight To Ouality. The Review of Economics and Statistics, 78, 1-15.

Berument, M. H., Ceylan, N. B., \& Dogan, B. (2014). An Interest-Rate-Spread-Based Measure of Turkish Monetary Policy. Applied Economics, 46, 1804-1813.

Calem, P. S., \& Mester, L. J. (1995). Consumer Behavior and The Stickiness of Credit-Card Interest Rates. The American Economic Review, 85, 1327-1336.

Chan, K.-S. (1993). Consistency and Limiting Distribution of The Least Squares Estimator of A Threshold Autoregressive Model. The Annals of Statistics, 21, 520-533.

Chen, H., Chand, S. S., \& Singh, B. (2020a). Impact of COVID-19 on Remittance Inflows to Samoa. Asian Economics Letters, 1. https://doi.org/10.46557/001c.17894

Chen, H., Chand, S.S, \& Singh, B. (2020b). Impact of Remittances on Private Sector Credit in The Pacific Island Countries. Buletin Ekonomi Moneter Dan Perbankan, 23, 13-32.

Devpura, N. (2020). Can Oil Prices Predict Japanese Yen? Asian Economics Letters, 1. https://doi.org/10.46557/001c.17964

Enders, W., \& Granger, C. W. J. (1998). Unit-Root Tests and Asymmetric Adjustment With An Example Using The Term Structure of Interest Rates. Journal of Business $\mathcal{E}$ Economic Statistics, 16, 304-311.

Enders, W., \& Siklos, P. L. (2001). Cointegration and Threshold Adjustment. Journal of Business \& Economic Statistics, 19, 166-176.

Gil-Alana, L. A., \& Claudio-Quiroga, G. (2020). The COVID-19 Impact on The Asian Stock Markets. Asian Economics Letters, 1. https://doi.org/10.46557/001c.17656

Han, H., \& Qian, Y. (2020). Did Enterprises' Innovation Ability Increase During the COVID-19 Pandemic? Evidence from Chinese Listed Companies. Asian Economics Letters, 1. https://doi.org/10.46557/001c.18072

Hannan, T. H., \& Berger, A. N. (1991). The Rigidity of Prices: Evidence from the Banking Industry. The American Economic Review, 81, 938-945.

Ho, S. Y., \& Iyke, B. N. (2018). Finance-Growth-Poverty Nexus: A Re-Assessment of The Trickle-Down Hypothesis in China. Economic Change and Restructuring, 51, 221-247. https://doi.org/10.1007/s10644-017-9203-8

Holton, S., \& d'Acri, C. R. (2018). Interest Rate Pass-Through Since The Euro Area Crisis. Journal of Banking \& Finance, 96, 277-291.

Iyke, B. N. (2017a). On the Term Structure of South African Interest Rates: Cointegration and Threshold Adjustment. International Journal of Sustainable Economy, 9, 300-321. https://doi.org/10.1504/IJSE.2017.087061 
Iyke, B. N. (2017b). Asymmetries in Yield Curves: Some Empirical Evidence from Ghana. Frontiers in Finance \& Economics, 14, 112-136

Iyke, B. N. (2020a). COVID-19: The Reaction of US Oil and Gas Producers to The Pandemic. Energy Research Letters, 1, 13912. https://doi.org/10.46557/001c.13912. Iyke, B. N. (2020b). Economic Policy Uncertainty in Times of COVID-19 Pandemic. Asian Economics Letters, 1. https://doi.org/10.46557/001c.17665.

Iyke, B. N. \& Ho, S.-Y. (2021). Investor Attention on COVID-19 and African Stock Returns. MethodsX, 8, 101195. https://doi.org/10.1016/j.mex.2020.101195.

Juhro, S. M., Narayan, P. K., Iyke, B. N., \& Trisnanto, B. (2020). Is There A Role for Islamic Finance and R\&D in Endogenous Growth Models in The Case of Indonesia?. Pacific-Basin Finance Journal, 62, 101297. https://doi.org/10.1016/j. pacfin.2020.101297

Karras, G. (1996). Are the Output Effects of Monetary Policy Asymmetric? Evidence from A Sample of European Countries. Oxford Bulletin of Economics and Statistics, 58, 267-278. https://doi.org/10.1111/j.1468-0084.1996.mp58002004.x

Li, X., Escalante, C. L., Epperson, J. E., \& Gunter, L. F. (2013). Agricultural Lending and Early Warning Models of Bank Failures for The Late 2000s Great Recession. Agricultural Finance Review, 73, 119-135.

Narayan, P. K. (2020a). Oil Price News and COVID-19-Is There Any Connection? Energy Research Letters, 1, 13176. https://doi.org/10.46557/001c.13176

Narayan, P. K. (2020b). Has COVID-19 Changed Exchange Rate Resistance to Shocks? Asian Economics Letters, 1. https://doi.org/10.46557/001c.17389

Narayan, P. K. (2020c). Did Bubble Activity Intensify During COVID-19? Asian Economics Letters, 1. https://doi.org/10.46557/001c.17654

Narayan, P. K., \& Popp, S. (2010). A New Unit Root Test With Two Structural Breaks in Level and Slope At Unknown Time. Journal of Applied Statistics, 37, 1425-1438.

Neumark, D., \& Sharpe, S. A. (1992). Market Structure and the Nature of Price Rigidity: Evidence from the Market for Consumer Deposits. The Quarterly Journal of Economics, 107, 657-680. https://doi.org/10.2307/2118485

Nguyen, C. V., \& Islam, A. M. (2010). Asymmetries in the Thai Lending-Deposit Rate Spread: An Econometric Analysis. Applied Economics Letters, 17, 1229-1236.

Phan, D. H. B., Iyke, B. N., Sharma, S. S., \& Affandi, Y. (2020). Economic Policy Uncertainty and Financial Stability-Is There A Relation? Economic Modelling, 94, 1018-1029. https://doi.org/10.1016/j.econmod.2020.02.042

Prabheesh, K. P. (2020). Dynamics of Foreign Portfolio Investment and Stock Market Returns During the COVID-19 Pandemic: Evidence from India. Asian Economics Letters, 1. https://doi.org/10.46557/001c.17658

Prabheesh, K. P., \& Laila, N. (2020). Asymmetric Effect Of Crude Oil And Palm Oil Prices on Economic Growth: Evidence From Indonesia. Buletin Ekonomi Moneter Dan Perbankan, 23, 253-268.

Prasad, K. (2017). Financial Sector Development Fiji Post 2000 (Reserve Bank of Fiji EGWP 2017-01). Suva: Reserve Bank of Fiji

Reserve Bank of Fiji. (2015). Quarterly Review - December 2015. Retrieved from Suva: https://www.rbf.gov.fj/getattachment/Publications-(1)/Quarterly-Reviews/ RBF-Quarter-Review_December-2015-(1).pdf.aspx 
Reserve Bank of Fiji. (2017). Fiji Financial Sector Development Plan 2016-2025. Retrieved from Suva: https://www.rbf.gov.fj/getattachment/a8d8c890-1df54dc7-bacf-dc7d0046fdee/Fiji-Financial-Sector-Development-Plan-2016-2025. pdf?lang=en-US

Rosen, R. J. (2002). What Goes Up Must Come Down? Asymmetries and Persistence in Bank Deposit Rates. Journal of Financial Services Research, 21, 173-193. https:// doi.org/10.1023/A:1015085826129

Scholnick, B. (1999). Interest Rate Asymmetries in Long-Term Loan and Deposit Markets. Journal of Financial Services Research, 16, 5-26. https://doi. org/10.1023/A:1008107030893

Sharma, P., Roca, E., Dakai, V., \& Manoa, S. (2014). An Assessment of Fiji's Banking Sector on a Global Scale: 2000-2011. (Reserve Bank of Fiji Policy Research Working Paper No. 1, 1-31). Reserve Bank of Fiji.

Sharma, S. S. (2020). A Note on the Asian Market Volatility During the COVID-19 Pandemic. Asian Economics Letters, 1. https://doi.org/10.46557/001c.17661

Stiglitz, J. E., \& Weiss, A. (1981). Credit Rationing in Markets with Imperfect Information. The American Economic Review, 71, 393-410.

Thompson, M. A. (2006). Asymmetric Adjustment in The Prime Lending-Deposit Rate Spread. Review of Financial Economics, 15, 323-329.

Weth, M. A. (2002). The Pass-Through from Market Interest Rates to Bank Lending Rates in Germany (Deutsche Bundesbank, Economic Research Centre Discussion Paper(11/02)). Deutsche Bundesbank. 
This page is intentionally left blank 